\title{
Totally endoscopic congenital heart surgery compared with the traditional heart operation in children
}

\author{
Yunge Cheng $\cdot$ Huaidong Chen $\cdot$ Wener Mohl $\cdot$ Xingzhu Liu $\cdot$ Zhongyi Si
}

Received: 23 October 2012 / Accepted: 23 September 2013 / Published online: 23 October 2013

(C) The Author(s) 2013. This article is published with open access at Springerlink.com

\begin{abstract}
Summary
Objective Totally endoscopic surgery compared with the conventional heart operation in children is described in this article to find a preferable treatment for congenital heart diseases.

Methods Between May 2000 and December 2007, 708 children with congenital heart disease were divided into two groups: endoscopic group and conventional group. For the endoscopic group, all children underwent total endoscopic procedures with peripheral cardiopulmonary bypass, transthoracic aortic cross-clamp, and antegrade cardioplegia, whereas for the conventional group, all children were operated in traditional way. Three $1-2-\mathrm{cm}$ intercostal ports in the right chest were used for access in the endoscopic group. The intrathoracic part of the operation was performed completely under two-dimensional video, using conventional instruments. Directly closureed of the atrial septal defect was performed in 74 cases, patch closureed of the atrial septal defect in 48 cases, directly closureed of the ventricular septal defect in 158 cases, patch closureing of the ventricular septal defect in 116 cases. For the conventional group, all operations were done with traditional median sternotomy. Directed closureing of the atrial septal defect was performed in 38 cases, patch closed of the atrial septal defect in 56 cases,
\end{abstract}

\footnotetext{
Z. Si, MD $(\bowtie) \cdot X$. Liu, MD

Department of Cardiovascular Surgery, the First Hospital,

Liaoning Medical University, Renmin Str. 5-2, Guta District,

Jinzhou 121001, Liaoning, China

e-mail: zhongyi85@hotmail.com

Y. Cheng, MD $\cdot$ H. Chen, MD

Department of Cardiovascular Surgery,

Shanghai Yodac Cardio-thoracic Hospital, Shanghai 201900, China

W. Mohl, MD, PhD

Department of Cardiothoracic Surgery, AKH,

Medical University of Vienna, 1090 Vienna, Austria
}

directly closureed of the ventricular septal defect in 76 cases, patch closureed of the ventricular septal defect in 142 cases.

Results There was no hospital mortality in both groups. For the endoscopic group, operations were performed successfully in $390(98.5 \%)$ patients, enlarging a port to a $5-\mathrm{cm}$ incision in 4 children. Reoperation was necessary in two children, and no conversion to median sternotomy incision was necessary. The mean duration of operation was $132 \pm 48 \mathrm{~min}$, and cardiopulmonary bypass and aortic cross-clamp times were $54 \pm 16 \mathrm{~min}$ and $25 \pm 8 \mathrm{~min}$, respectively. Major postoperative complications occurred in nine $(2.3 \%, p<0.05)$ cases. For the conventional group, all children were operated by median sternotomy, and the mean duration of operation was $118 \pm 41 \mathrm{~min}(p<0.05)$; cardiopulmonary bypass and aortic cross-clamp times were $51 \pm 13 \mathrm{~min}$ and $21 \pm 6 \mathrm{~min}$ $(p<0.05)$, respectively. Major postoperative complications occurred in $16(5.1 \%)$ cases. Also, the intensive care unit stay time $(8.3 \pm 2.8 \mathrm{~h}$ versus $8.9 \pm 2.9 \mathrm{~h}, p<0.01)$, postoperative drainage $(120 \pm 21 \mathrm{ml}$ versus $433 \pm 140 \mathrm{ml}$, $p<0.05)$, and hospital time ( $8.6 \pm 1.8$ days versus $11.5 \pm 1.9$ days, $p<0.05)$ were statistically different.

Conclusions Totally endoscopic closed chest congenital heart surgery in children was feasible and safe. The results were similar or even superior to the traditional operations due to the decreased use of blood products and shortened hospital time. Degree of satisfaction with cosmetic result and postoperative comfort were very high. Therefore, endoscopic surgery will become a new popular choice for some congenital heart disease patients in the future.

Keywords Endoscopic cardiac surgery - Minimally invasive cardiac surgery $\cdot$ ASD repair · VSD repair - Congenital heart surgery 
Komplett endoskopische Herzchirurgie kongenitaler Herzfehler im Vergleich zu traditioneller Herzchirurgie bei Kindern

\section{Zusammenfassung}

Ziel Um zu klären, welcher Therapie der Vorzug zu geben ist, wird die total endoskopische Herzchirurgie mit der konventionellen Herzchirurgie bei Kindern mit kongenitalen Herzfehlern im vorliegenden Artikel verglichen.

Methodik Zwischen Mai 2000 und Dezember 2007 wurden 708 Kinder mit kongenitalen Herzfehlern in 2 Gruppen geteilt: eine Gruppe wurde komplett endoskopisch, die andere Gruppe konventionell operiert. Bei der endoskopischen Gruppe wurden alle Kinder endoskopisch mit peripherem kardiopulmonalem Bypass, transthorakaler Aortenklemmung und antegrader Kardioplegie operiert. Die konventionelle Gruppe wurde in traditioneller Weise operiert. Drei 1-2 cm große interkostale Ports im Bereich des rechten Thorax dienten als Zugang bei der endoskopischen Gruppe. Der intrathorakale Teil der Operation wurde ausschließlicher mittels zweidimensionalen Video unter Verwendung konventioneller Instrumente durchgeführt.

Ein direkter Verschluss des Vorhofseptums wurde in 74 Fällen durchgeführt, ein Verschluss mit Patch in 48, ein direkter Verschluss eines Ventrikelseptumdefekts in 158 Fällen ein Verschluss mit Patch bei 116 Fällen, assoziiert mit abnormaler Veneneinmündung in 3 Fällen, eine Mitralklappen Annuloplastie in 4 Fällen, subpulmonale Arterienmuskelresektion in 6 Fällen.

Bei der konventionellen Gruppe war bei allen Operationen die traditionelle mediane Sternotomie der Operationszugang. Ein Vorhofseptumdefekt wurde bei 38 Fällen direkt verschlossen, bei 56 mit Patch. Bei 76 Patienten wurde ein Ventrikelseptumdefekt direkt verschlossen, mit Patch in 142 Fällen - mit assoziierter partiell abnormaler Venenverbindung in 24 Fällen. Eine Mitralklappen Annuloplastie wurde bei 8 Patienten und eine subpulmonale Arterienmuskelresektion in 18 Fällen durchgeführt.

Ergebnisse Bei beiden Gruppen war die Mortalität im Spital gleich null.

Bei der endoskopischen Gruppe lag die Erfolgsrate bei $98,5 \%$ (390 Kinder), wobei bei 4 Patienten die Inzision des Ports auf $5 \mathrm{~cm}$ erweitert werden musste. Eine Reoperation war bei 2 Kindern notwendig, ein Umsteigen auf die mediane Sternotomie war nie notwendig. Die mittlere Operationsdauer lag bei $132 \pm 48 \mathrm{~min}$, die Zeit am kardiopulmonalen Bypass und die Aortenklemmzeit $54 \pm 16 \mathrm{~min}$ beziehungsweise $25 \pm 8$ Minuten. Schwere postoperative Komplikationen traten bei $9(2,3 \%$, $p<0,05)$ Kindern auf. Die mittlere Operationszeit lag bei den konventionell operierten Kindern bei $118 \pm 41 \mathrm{~min}$ $(p<0,05)$, die kardiopulmonale Bypasszeit beziehungsweise die Aortenklemmzeit bei $51 \pm 13$ und $21 \pm 6$ min $(p<0,05)$. Schwere postoperative Komplikationen traten bei $16(5,1 \%)$ Kindern auf. Auch die auf der Intensivstation verbrachte Zeit $(8,3 \pm 2,8 \mathrm{~h}$ versus $8,9 \pm 2,9 \mathrm{~h}, p<0,01)$ war ebenso wie die postoperative Drainage $(120 \pm 21 \mathrm{ml}$ versus $433 \pm 140 \mathrm{ml}, p<0,05)$, und die im Spital ver- brachte Zeit ( $8,6 \pm 1,8$ Tage versus $11,5 \pm 1,9$ Tage, $p<0,05)$ statistisch signifikant unterschiedlich.

Schlussfolgerungen Die komplett endoskopisch bei geschlossenem Thorax durchgeführte Operation kongenitaler Herzfehler bei Kindern ist durchführbar und ein sicheres Verfahren. Die Ergebnisse waren mit denen der konventionellen Operationstechnik vergleichbar oder auf Grund der geringeren Verwendung von Blutprodukten und kürzerer Spitalsaufenthaltsdauer sogar besser. Der Zufriedenheitsgrad mit dem kosmetischen Ergebnis und das postoperative Wohlbefinden waren sehr hoch. Daher wird die endoskopische Operationstechnik in der Zukunft eine neue Popularität bei der Korrektur mancher Patienten mit kongenitalen Herzfehlern erreichen.

Schlüsselwörter Endoskopische Herzchirurgie · Minimal invasive Herzchirurgie - ASD Korrektur · VSD Korrektur
Abbreviations
ASD Atrial septal defect
VSD Ventricular septal defect
CPB Cardiopulmonary bypass
SVC Superior vena cava
IVC Inferior vena cava
ICS Intercostal space

\section{Introduction}

Standard congenital heart surgery via sternotomy is a safe and effective procedure with low morbidity and mortality. Minimally invasive procedure avoiding sternotomy is convincingly desirable and performed through a right anterolateral thoracotomy [1]. The length of incision can be reduced to $4-10 \mathrm{~cm}$. The clinical introduction of robotically assisted surgery further reduced skin incisions and enabled totally endoscopic procedures through ports in adults [2, 3]. To find a preferable treatment, 708 patients with congenital heart disease, divided into endoscopic group and traditional group according to different surgical methods, were described as follows.

\section{Patients and methods}

Between May 2000 and December 2007, 708 children with congenital heart disease underwent two different surgical treatments: the endoscopic surgery and the conventional operation, according to the requests of their parents and an approval by the ethics committee. For endoscopic group, 396 patients were included (181 males and 215 females). The average age was $9.4 \pm 3.1$ (range: 5-12) years, and the body weight was $29.5 \pm 9.9$ (range: 15-40.0) kg. Diagnosis consisted of ventricular septal defect (VSD) in 274 cases, atrial septal defect (ASD) in 122 cases, associated partial anomalous venous connections in 4 patients, subpulmonary artery anomalous muscle in 6 patients, and mitral valve regurgitation in 
4 patients. Left ventricular ejection fraction was within the normal range in all children, and mean pulmonary artery pressure was $38 \pm 7(22-56) \mathrm{mmHg}$. For the conventional group, 312 patients were included (157 males and 155 females). The average age was $6.6 \pm 1.9$ years, and the body weight was $23.2 \pm 7.1 \mathrm{~kg}$. In total, 96 patients were diagnosed as having ASD, and 218 patients had VSD, accompanied with partial anomalous venous connections in 24 patients, subpulmonary artery anomalous muscle in 18 patients, mitral valve regurgitation in 8 patients, and patent ductus arteriosus in 54 patients. Left ventricular ejection fraction was also within the normal range in all children, and mean pulmonary artery pressure was $41 \pm 6 \mathrm{mmHg}$ (Table 1).

\section{Surgical techniques}

For traditional group, the surgery was executed via median sternotomy under general anesthesia, whereas for endoscopic group, after the induction of anesthesia, an intraoperative transesophageal echocardiography was performed. The patient was positioned in a $20-30^{\circ}$ left lateral decubitus position. After systemic heparinization, femoral vessels were accessed through an oblique

Table 1 The characteristics of patients

\begin{tabular}{|c|c|c|c|}
\hline Characteristics & $\begin{array}{l}\text { Endoscopic } \\
\text { group }(n=396)\end{array}$ & $\begin{array}{l}\text { Traditional } \\
\text { group }(n=312)\end{array}$ & $p$-value \\
\hline Age (years) & $9.4 \pm 3.1$ & $6.6 \pm 1.9$ & 0.882 \\
\hline Body weight (kg) & $29.5 \pm 9.9$ & $23.2 \pm 7.1$ & 0.596 \\
\hline Sex & & & 0.222 \\
\hline Male & $181(45.70 \%)$ & $157(50.32 \%)$ & \\
\hline Female & $215(54.30 \%)$ & $155(49.68 \%)$ & \\
\hline NYHA class & & & 0.598 \\
\hline I & $281(71.00 \%)$ & $227(72.76 \%)$ & \\
\hline$\|$ & $115(29.00 \%)$ & $85(27.24 \%)$ & \\
\hline Ejection fraction (\%) & $68.3 \pm 8.4$ & $63.4 \pm 8.1$ & 0.083 \\
\hline Etiology (number of patients) & & & 0.845 \\
\hline ASD & $122(30.80 \%)$ & $94(30.13 \%)$ & \\
\hline VSD & $274(69.20 \%)$ & $218(69.87 \%)$ & \\
\hline Membranous VSD & $189(68.98 \%)$ & $146(66.97 \%)$ & \\
\hline Muscular VSD & $85(31.02 \%)$ & $72(33.03 \%)$ & \\
\hline $\begin{array}{l}\text { Pulmonary artery pressure } \\
(\mathrm{mmHg})\end{array}$ & $38 \pm 7$ & $41 \pm 6$ & 0.063 \\
\hline \multicolumn{4}{|c|}{ With diseases (number of patients) } \\
\hline $\begin{array}{l}\text { Partial anomalous venous } \\
\text { connections }\end{array}$ & 4 & 24 & 0.000 \\
\hline $\begin{array}{l}\text { Subpulmonary artery } \\
\text { anomalous muscle }\end{array}$ & 6 & 18 & 0.002 \\
\hline Mitral valve regurgitation & 4 & 8 & 0.112 \\
\hline Patent ductus arteriosus & 0 & 54 & 0.000 \\
\hline
\end{tabular}

incision along the inguinal crease. A $12-17 \mathrm{~F}$ arterial cannula was inserted into the common femoral artery. A $15-21 \mathrm{~F}$ venous cannula was inserted through the right femoral vein into the inferior vena cava (IVC). A 12-mm endoscopic trocar was used, through which a $30^{\circ} 10-\mathrm{mm}$ endoscopic camer was placed into the right thoracic cavity. The second $15-\mathrm{mm}$ port incision was made at the third ICS along the right parasternum to allow insertion of the right-hand instruments, such as shears, needle forceps, and suctor. The third $15-\mathrm{mm}$ port incision was made at the third ICS on the midaxillary line, to allow insertion of the aortic cross-clamp, the left-hand instruments, and the superior vena cava (SVC) cannulas through the fourth ICS. The intrathoracic part of the operation was done completely under two-dimensional video, beginning with pericardiotomy and placement of pericardial traction sutures. The SVC and IVC were dissected, and they were snared with an umbilical tape. The additional vein cannula (17-21F, DLP, Metronic) was inserted into the SVC through the third port in the fourth ICS. Cardiopulmonary bypass (CPB) was established between the femoral arteries, the femoral veins, and the SVC. After $\mathrm{CPB}$ initiation and cooling to $32^{\circ} \mathrm{C}$, the ascending aorta was cross-clamped with a transthoracic aortic crossclamp through the third port, an antegrade cardioplegia needle was inserted into the ascending aorta, and cardiac arrest was achieved by delivering cold cardioplegic solution directly into the aortic root. After blocking of the SVC and IVC superior and inferior venae cavae, the right atrium was opened. For the closure of ASD, four stay sutures were placed on the atrial roof to expose the ASD. Anatomic landmarks, including the fossa ovalis, coronary sinus ostium, and eustachian valve, were identified. According to the size of the defect, the ASD was directly closed using double-layer 4-0 Prolene running suture in 74 cases, patch closed using a 4-0 Prolene running suture in 48 cases, and associated with partial anomalous venous connections rectification in 3 cases, and mitral valve annuloplasty in 2 cases. For the closure of VSD, the vent catheter for drainage was inserted into the left atrium through the ASD. The tricuspid valve and the right ventriculear were tractive using a specially designed retractor through the second port to expose the VSD. The VSD was directly closed in 158 cases, patch closed in 116 cases, and associated with subpulmonary artery muscle resection in 6 cases. Before the suture of the atrial septum was tied, blood was perfused in the left atrium to de-air. Antegrade de-airing was done from the ascending aorta through the needle vent. Air was removed by inflating the lungs and simultaneous reduction of venous drainage with the patient in the Trendelenburg position. The right atrium was closed using a 4-0 Prolene running suture. After stopping CPB, patients were weaned from CPB, and a tube for postoperative drainage was inserted into the right thorax cava right thoracic cavity through the first port (Table 2). 
Table 2 Surgical procedure and operative time

\begin{tabular}{|c|c|c|c|}
\hline Variables & $\begin{array}{l}\text { Endoscopic } \\
\text { group }(n=396)\end{array}$ & $\begin{array}{l}\text { Traditional } \\
\text { group }(n=312)\end{array}$ & $p$-value \\
\hline Concomitant procedure & & & 0.845 \\
\hline ASD & 122 & 94 & \\
\hline Direct suture & $74(60.66 \%)$ & $38(40.43 \%)$ & \\
\hline Pericardia patch & 48 (39.34\%) & 56 (59.57 \%) & \\
\hline Mitral valve annuloplasty & 2 & 3 & \\
\hline VSD & 274 & 218 & \\
\hline Direct suture & $158(57.66 \%)$ & $76(34.86 \%)$ & \\
\hline $\begin{array}{l}\text { Dacron polyester fiber } \\
\text { patch }\end{array}$ & $116(43.37 \%)$ & $142(65.14 \%)$ & \\
\hline Mitral valve annuloplasty & 2 & 5 & \\
\hline $\begin{array}{l}\text { Subpulmonary artery } \\
\text { muscle resection }\end{array}$ & 6 & 18 & \\
\hline \multicolumn{4}{|l|}{ Operative time (min) } \\
\hline Cross-clamp time & $25 \pm 8$ & $21 \pm 6$ & 0.021 \\
\hline $\begin{array}{l}\text { Cardiopulmonary bypass } \\
\text { time }\end{array}$ & $54 \pm 16$ & $51 \pm 13$ & 0.007 \\
\hline Operative time & $132 \pm 48$ & $118 \pm 41$ & 0.033 \\
\hline Mechanical ventilation (h) & $4.3 \pm 1.6$ & $4.1 \pm 1.5$ & 0.091 \\
\hline $\begin{array}{l}\text { Intensive care unit stay } \\
\text { times (h) }\end{array}$ & $8.3 \pm 2.8$ & $8.9 \pm 2.9$ & 0.007 \\
\hline Postoperative drainage (ml) & $120 \pm 21$ & $433 \pm 140$ & 0.020 \\
\hline Hospital time (days) & $8.6 \pm 1.8$ & $11.5 \pm 1.9$ & 0.015 \\
\hline
\end{tabular}

\section{Statistical analysis}

SPSS 13.0 software was used for analysis. Chi-square test and $t$-test were adopted for enumeration data and quantitative data, respectively. The difference between two groups was statistically significant when $p$-value was equal to or less than 0.05 .

\section{Results}

There were no hospital deaths for both groups. All operations were successful for the conventional group, whereas for the endoscopic group, the operation was performed successfully in 390 (98\%) patients, enlarging a port to a $5-6-\mathrm{cm}$ incision in 4 patients due to the bleeding of the aortic root. A retractor was used and surgical tasks were performed for controlling the bleeding under direct vision. Residual shunt was detected during postoperative echocardiography in 14 children, and reoperation was done in 2 children. The procedure was performed through a minithoracotomy at the fourth ICS, and no conversion to median sternotomy incision was necessary.

The mean duration of operation was $132 \pm 48$ versus $118 \pm 41(p<0.05) \mathrm{min}$, and the mean durations of CPB and aortic cross-clamp were $54 \pm 16$ versus $51 \pm 13$ $(p=0.007) \mathrm{min}$ and $25 \pm 8$ versus $21 \pm 6(p<0.05) \mathrm{min}$ for the endoscopic group and the traditional group, respec-
Table 3 Results of clinical and echocardiographic follow-up

\begin{tabular}{|c|c|c|c|}
\hline Variables & $\begin{array}{l}\text { Endoscopic } \\
\text { group }(n=396)\end{array}$ & $\begin{array}{l}\text { Traditional } \\
\text { group }(n=312)\end{array}$ & $p$-value \\
\hline Performed successfully & 390 & 312 & \\
\hline Enlarge the right-hand port & 4 & 0 & \\
\hline $\begin{array}{l}\text { Postoperative complications } \\
\text { (number of patients) }\end{array}$ & 9 & 16 & 0.039 \\
\hline Re-exploration for bleeding & 1 & 6 & \\
\hline Impaired wound healing & 3 & 10 & \\
\hline Hemopneumothorax & 5 & 0 & \\
\hline Residual shunt & 14 & 0 & 0.000 \\
\hline Reoperation & 2 & 0 & \\
\hline \multicolumn{4}{|c|}{ Echocardiographic follow-up (mean $12.4 \pm 3.5$ months) } \\
\hline Residual shunt disappeared & 8 & 0 & \\
\hline Residual shunt (2 mm) & 6 & 0 & \\
\hline Mild tricuspid regurgitation & 22 & 18 & 0.903 \\
\hline Ejection fraction (\%) & $70.5 \pm 6.3$ & $68.3 \pm 6.1$ & 0.055 \\
\hline
\end{tabular}

tively. Also, the postoperative ventilation time was $4.3 \pm 1.6$ versus $4.1 \pm 1.5(p=0.09) \mathrm{h}$, intensive care unit time was $8.3 \pm 2.8$ versus $8.9 \pm 2.9(p=0.007) h$, postoperative hospital stay time was $8.6 \pm 1.8$ versus $11.5 \pm 1.9$ $(p<0.05)$ days, and postoperative drainage was $120 \pm 21$ versus $433 \pm 140(p<0.05) \mathrm{ml}$, respectively (Table 2$)$.

Major postoperative complications occurred in 9 versus 16 cases for endoscopic group and traditional group, respectively (Table 3 ).

\section{Discussion}

Patients and doctors are eager to cure the simple ASD and VSD in children using a minimally invasive repair. Closure of the defect in the catheterization laboratory using the clamshell device technique is the least invasive and has substantially shifted the treatment of ASD and VSD from the surgeon toward the interventionist. Some centers have applied this technique, and it would be considered as a standard approach in the future. However, several types of defects are beyond the scope of transcatheter treatment, and recurrence and occluder dislodgment have also been reported [4]; therefore, a cosmetic and safer surgical treatment is sought. A totally endoscopic approach may be considered as an adjunct to the already-existing interventional treatment options. Totally endoscopic ASD repair in adult could be performed with computer-enhanced telemanipulation [2]. Criticisms of this approach by use of surgically robotic syetem included the severity indication; the longer time of operation, $\mathrm{CPB}$, and aortic cross-clamp; the more expensive, therfore it is not used frequently by all cardiac surgeons; and its limited use in some medical centers.

Over the past 20 years, endoscopic surgery has been one of the great achievements of surgery. Endoscopic surgery does not provide any new treatment methods, but rather than a different approach to cure the different 
diseases. Port access is an attractive approach for some patients, especially for young female patients favoring the small and cosmetic incision. The experience of endoscopic surgery in other specialties can serve as means for cross-fertilization for totally endoscopic cardiac surgery. The surgical robot is only one of the several tools that must be used to achieve the technical goals of closed chest cardiac surgery, and our study has provided additional widening possibility to the closed chest cardiac surgery also, as described in this article. ASD and VSD repair in children can be performed totally under twodimensional endoscopic imaging through three ports, using conventional instrumentation except the femoral cannulation. The results and cost effectiveness are similar to the traditional operations, and some of the cost was even lesser than the traditional operations due to the decreased consumption of blood products and shorter hospital days. The cost was markedly lesser than that of the transcatheter closure of defects. In our series, some of the children had the indication for transcatheter treatment, but they selected totally endoscopic procedure due to economic reasons.

Totally endoscopic cardiac surgery is not one complex technique. The skill of cardiac surgeon performing the endoscopic instrument is the key point of successful operation. Cardiac surgeons need to train systematically, and learning curve is one of the most important factors for performing totally endoscopic surgery. Even though we had performed 100 experiments in animals experiment for totally endoscopice cardiac surgery through three ports, the time of learning and training should be continued while the technical problems often appeared in the initial operations by using totally endoscopic heart operation technique. Three enlarging incisions and four residual shunts occurred earlier in our overall experience. The skills still contribute to the longer duration of operation, cpb, and aortic cross-clamp. In the beginning of using this technique, only ostium secundum-type ASD was selected for totally endoscopic repairs. With growing experience, other types of ASD and VSD with other comorbidities as described previously were also included. The enlarging rate and residual shunt rate of totally endoscopic cardiac surgery were kept very low. The durations of operation, $\mathrm{CPB}$, and aortic cross-clamp were obviously decreased, almost similar to the traditional techniques. Further clinical experience and data are necessary; however, we think that totally endoscopic cardiac surgery is a viable option [3]. More and more problems would be overcome with more clinical experience and the development of new accessory instruments, such as retraction systems, perfusion catheters, and sutureless anastomotic devices. With such advances and continued success from pioneering centers, completely endoscopic cardiac surgery may become a widely available clinical reality in the near future.

\section{Conclusions}

Totally endoscopic closed chest congenital heart surgery in children was feasible and safe. The results were similar or even superior to the traditional operations due to the decreased use of blood products and shortened hospital time. Degree of satisfaction with cosmetic result and postoperative discomfort were very high. Therefore, endoscopic surgery will become a new popular choice for some congenital heart disease patients in the near future.

\section{Conflict of interest}

The authors declare that there is no conflict of interest.

\section{Open Access}

This article is distributed under the terms of the Creative Commons Attribution Noncommercial License which permits any noncommercial use, distribution, and reproduction in any medium, provided the original author(s) and the source are credited.

\section{References}

1. Ryan WH, Cheirif J, Dewey TM, et al. Safety and efficacy of minimally invasive atrial septal defect closure. Ann Thorac Surg. 2003;75:1532-4.

2. Kim JE, Jung SH, Kim GS, et al. Surgical outcomes of congenital atrial septal defect using da VinciTM surgical robot system. Korean J Thora Cardiovas Surg. 2013;46:93-7.

3. Ma ZS, Wang JT, Dong MF, et al. Thoracoscopic closure of ventricular septal defect in young children: technical challenges and solutions. Eur J Cardiothorac Surg. 2012;42:976-9.

4. Mishaly D, Ghosh P, Preisman S. Minimally invasive congenital cardiac surgery through right anterior minithoracotomy approach. Ann Thorac Surg. 2008;85:831-5. 